University of Nebraska - Lincoln

DigitalCommons@University of Nebraska - Lincoln

Faculty Publications from the Harold W. Manter Laboratory of Parasitology

$10-1980$

\title{
Contracaecum multipapillatum ( $=C$. robustum) from Fishes and Birds in the Northern Gulf of Mexico
}

Thomas L. Deardorff

Exponent, tdeardorff@exponent.com

Robin M. Overstreet

Gulf Coast Research Laboratory, robin.overstreet@usm.edu

Follow this and additional works at: https://digitalcommons.unl.edu/parasitologyfacpubs

Part of the Parasitology Commons

Deardorff, Thomas L. and Overstreet, Robin M., "Contracaecum multipapillatum (=C. robustum) from Fishes and Birds in the Northern Gulf of Mexico" (1980). Faculty Publications from the Harold W. Manter Laboratory of Parasitology. 462.

https://digitalcommons.unl.edu/parasitologyfacpubs/462

This Article is brought to you for free and open access by the Parasitology, Harold W. Manter Laboratory of at DigitalCommons@University of Nebraska - Lincoln. It has been accepted for inclusion in Faculty Publications from the Harold W. Manter Laboratory of Parasitology by an authorized administrator of DigitalCommons@University of Nebraska - Lincoln. 
J. Parasitol., 66(5), 1980, pp. 853-856

\section{Contracaecum multipapillatum (=C. robustum) from Fishes and Birds in the Northern Gulf of Mexico}

Thomas L. Deardorff and Robin M. Overstreet, Gulf Coast Research Laboratory, Ocean Springs, Mississippi 39564

This note clarifies the taxonomic status of the ascaridoid Contracaecum robustum Chandler 1935 based on larval development, investigates the nematode's potential as a public health hazard, and reports the relative prevalence of it and related species along the northern Gulf of Mexico.

Third-stage larvae $\left(\mathrm{L}_{3}\right.$ 's) of various species of Contracaecum Railliet and Henry 1912 have been reported from fishes in the Gulf of Mexico and adjacent waters (Chandler, 1935, Proc. U.S. Natl. Mus. 83: 123-157; Hutton, 1964, Trans. Am. Microsc. Soc. 83 : 439-447; Nikolaeva and Parukhin, 1968, in Studies of
Central American seas, Z. Yankovskaya [ed.]), but their status is uncertain. Some of these $\mathrm{L}_{3}$ 's probably are not Contracaecum sensu stricto (see Deardorff and Overstreet, 1980, Review of Hysterothylacium and Iheringascaris $[$ both previously $=$ Thynnascaris $]$ [Nematoda: Anisakidae] from the northern Gulf of Mexico, Proc. Biol. Soc. Wash. 93: 1035-1079).

Adult features, and therefore taxonomic status, of C. robustum larvae encapsulated in the liver, kidneys, and mesentery of mullets $(\mathrm{Mu}$ gil cephalus, M. curema, and probably Liza ramada [as $M$. capito] and others) have not 
Deardorff \& Overstreet in Journal of Parasitology (1980) 66. Copyright 1980, American Society of Parasitologists. Used by permission.

been established. Some consider it to be the larval stage of C. microcephalum (Rudolphi 1809) (e.g., Chandler, op. cit.), and others give it specific status (e.g., Nikolaeva and Naidenova, 1964, Tr. Sevastop. Biol. Stn. Akad. Nauk Ukr. SSR 17: 125-158). Araujo (1970, Rev. Farm. Bioquim. Univ. São Paulo 8: 103-113) transferred it to the genus Cerascaris Cobb 1929, and Skinner (1975, Bull. Mar. Sci. 25: 318-347) considered specimens of it as Thynnascaris $\mathrm{sp}$. The genus Cerascaris is based on larval characters, and we agree with Yamaguti (1962, Systema Helminthum, Vol. III. The nematodes of vertebrates, Interscience, New York, 1261 p.) that Cerascaris is a junior synonym, probably of Contracaecum sensu stricto. Skinner kindly loaned us specimens identified as Thynnascaris sp. from cysts in the liver and mesentery of $M$. cephalus in Biscayne Bay, Florida. We did not find the excretory pore located near the level of the nerve ring and consider the specimens identical to those that we, and presumably Chandler, call C. robustum from the northern Gulf of Mexico. Because this larva causes some people to discard "wormy" or all mullet, either for esthetic reasons or as an assumed public health hazard (Overstreet, 1978, Marine maladies? Worms, germs, and other symbionts from the northern Gulf of Mexico, Mississippi-Alabama Sea Grant Consortium, Ocean Springs, Mississippi, 140 p.), we sought to identify it and determine if it caused lesions. Related ascaridoid nematodes cause human anisakiasis (Jackson, 1975, J. Milk Food Technol. 38: 769-733).

In order to determine if $C$. robustum would develop in, or harm, a host, we administered worms orally by gavage to one day-old chick, one day-old mallard duckling, and 22 laboratory rats (Charles Rivers Laboratories $\mathrm{Crl}: \mathrm{COBS}^{\circledR} \mathrm{CD}{ }^{\circledR}[\mathrm{SD}] \mathrm{BR}$ ) and surgically by inserting them into either the stomach by way of the abdominal cavity or directly into the cavity of 25 rats, 24 white mice, two hamsters, and two chickens. Of the gavaged rats, 14 received one larva and eight received five; up to 10 larvae were surgically placed into each of the other animals. All nematode specimens given to animals came from the liver and kidneys of the striped mullet, M. cephalus, or the mesentery of the red drum, Sciaenops ocellata, and allowed to excyst in $0.8 \% \mathrm{NaCl}$ for $24 \mathrm{hr}$.

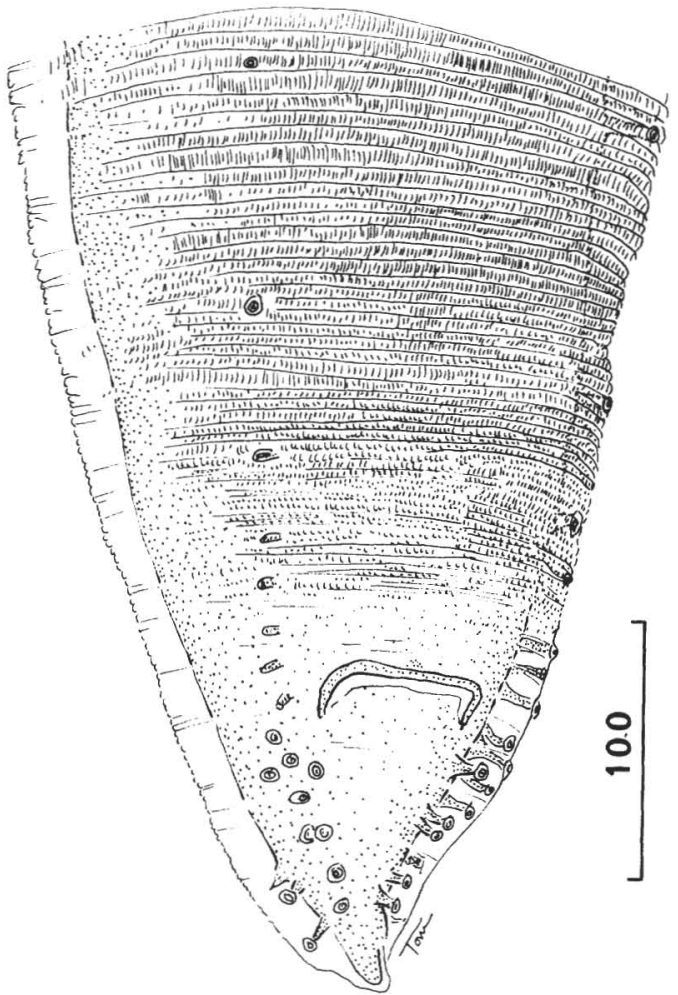

FIGURE 1. Contracaecum multipapillatum from Mugil cephalus. Posterior end of early $\mathrm{L}_{5}$ developed in rat showing ventral annular crests and postanal and para-anal papillae; ventral view.

Contracaecum robustum showed no ability to harm the experimental animals. No individuals penetrated through or into the alimentary tract of any of the five animals tested within $72 \mathrm{hr}$, at which time all worms had died or had been defecated. However, worms inserted into the abdominal cavity of rats survived for long periods. Three rats examined at $9 \mathrm{mo}$, each originally given eight worms, had eight, five, and no viable $L_{3}$ 's encapsulated in the mesentery. Even though the larval nematodes did not cause pathogenic reactions in the animals we tested, Contracaecum spp. on occasion caused lesions in the proventriculus of pelicans and other bird hosts (Huizinga, 1971, J. Wildl. Dis. 7: 198-204; Liu and Edward, 1971, J. Wildl. Dis. 7: 266-271), and an immature, unidentified species in Japan caused a granuloma in dogs that ate fish (Kitayama et al., 1967, Jpn. J. Parasitol. 16: 28$35)$. 
Four worms developed to an $\mathrm{L}_{5}$ stage in the abdominal cavity of rats by day 10 . There were a male and female from both the mullet and red drum, and these developed enough to allow an identification. We identified them as C. multipapillatum (von Drasche 1882), reducing $C$. robustum to its junior synonym. Specimens were 19 to $25 \mathrm{~mm}$ long, with lips slightly longer than wide. The esophagus and spicules were 12 to $14 \%$ and 3 to $6 \%$ of the body length, respectively. Ratios of the lengths of ventricular appendage to that of esophagus equaled 1:5.6-7.3, of intestinal cecum to esophagus was 1:1.1-1.3, and of intestinal cecum to ventricular appendage was 1:0.1-0.2. As many as 125 pairs of preanal papillae extended along the posterior third of the males, and of the seven postanal papillar pairs, the fifth from the posterior extremity appeared doubled. Three pairs of para-anal papillae occurred slightly posterior to the anus and lateral to it. Minute ventral crests on annules (Fig. 1) extended from near the anus of these males to the anteriormost papillae. In the female, the vagina opened within the anterior 17 to $25 \%$ of the body.

Contracaecum multipapillatum infects the proventriculus of numerous amphi-American fish-eating birds (e.g., Lucker, 1941, J. Parasitol. 27: 505-512; Baruš, 1966, Poeyana Inst. Biol. Habana Ser. A, No. 22, 37 p; Courtney and Forrester, 1974, Proc. Helminthol. Soc. Wash. 41: 89-93). Unconfirmed reports of larval C. robustum in Japan (Fujita, 1940, Jpn. J. Zool. 8: 377-394) and the Adriatic Sea (Nikolaeva and Niadenova, op. cit.) and unidentified larvae in mullet from Mexico (SalgadoMaldonado, 1978, An. Inst. Biol. Univ. Nal. Autón México Ser. Zool. 49: 71-82), Peru (Armas, 1979, J. Fish Dis. 2: 543-547), the Middle East (Baylis, 1923, Parasitology 15: 1-13; Shamsuddin et al., 1971, Bull. Biol. Res. Cntr. Baghdad 5: 66-78), and elsewhere suggest a wider occurrence of the parasite, credible because some bird-hosts migrate extensively. Specimens referred to as "C. robustum" are apparently restricted to few hosts. We saw few fishes concurrent with mullet and red drum infected with similar appearing larvae. On the other hand, Bangham (1940, Proc. Fl. Acad. Sci. 5: 289-307) identified larvae from several freshwater fishes in Florida as C. $s p i$ culigerum (Rudolphi 1809) that may have included C. multipapillatum in part. When
Huizinga (1967, J. Parasitol. 53: 368-375) clarified part of the life cycle of C. multipapillatum, he identified his specimens from Anhinga anhinga leucogaster on the basis of Lucker's work (op. cit.), the same as we did, but did not relate his material to C. robustum. He found that the $\mathrm{L}_{2}$ 's in some copepods exsheathed and, thereby, became able to infect the guppy which in turn were infective to the paratenic largemouth bass. Whether mullet become infected from free-living $\mathrm{L}_{2}$ 's or infected copepods is not known. In any event, the Brown Pelican picks up infections by the time it is 2-wk-old and begins feeding heavily on mullet at fledging (Courtney and Forrester, op. cit.; Humphrey et al., 1978, Wilson Bull. 90: 587-598).

Prevalence varied according to locality and period examined. We saw heavy infections of adult $C$. multipapillatum in the Doublecrested Cormorant, Phalacrocorax auritus, from Rockefeller Refuge, Louisiana, where mullet also are heavily infected and fed upon by the cormorant. Along the Mississippi coast, the prevalence of infections in mullets is presently low. At this time, few cormorants live there. A few permanently residing Brown Pelicans live in nearby Mobile Bay and Louisiana. These populations contrast with the large numbers present in 1958 (William Demoran, pers. comm.) when we understand mullet were especially "wormy." Relatively large flocks of both the Brown Pelican and White Pelican presently migrate annually through coastal Mississippi, and two individuals of the White Pelican, Pelecanus erythrorhynchos, that died in Mississippi during these migrations plus an examined, resident cormorant, Louisiana Heron, Hydranassa tricolor, and Green Heron, Butorides virescens, had light infections of $C$. multipapillatum. We examined moderately heavy infections of nematodes from the Brown Pelican, P. occidentalis, collected by Courtney (see Courtney and Forrester, op. cit.) and Richard Heard (unpubl.) from various locations in Florida, plus one migrating specimen that died in Mississippi.

Contracaecum rudolphii Hartwich 1964, commonly occurring concurrently with $C$. multipapillatum in pelicans from the southeastern U.S., has been variously identified. Huizinga (1966, Elisha Mitchell Sci. Soc. 82: 181-195), who studied its life cycle, and 
Deardorff \& Overstreet in Journal of Parasitology (1980) 66.

Copyright 1980, American Society of Parasitologists. Used by permission.

Courtney and Forrester (op. cit.) called it $C$. spiculigerum. Hartwich (1964, Mitt. Zool. Mus. Berlin 40: 15-53) considered that more than one species went by $C$. spiculigerum and erected C. rudolphii for those specimens reported by Huizinga and by others. This name has been accepted by most recent workers (see references listed by Baruš et al., 1978, Helminths of fish-eating birds of the Palaearctic Region I, Nematoda. W. Junk, Publ., Czech. Acad. Sci., Prague, 318 p.), but there are several possible and proposed, older synonyms. In fact, our specimens from the Double-crested Cormorant, White Pelican, Brown Pelican, and Least Bittern, Ixobrychus exilis, collected in Mississippi, as well as additional specimens from Louisiana and Florida were identified as C. microcephalum (Rudolphi 1809) using the key by Baruš et al. (op. cit). The interlabial tips are rounded in adults, rather than bifurcated as reported for C. rudolphii. On the other hand, the 4.7- to 6.2-mm-long spicules in 12 males 21.0 to $34.5 \mathrm{~mm}$ long are 18 to $25 \%$ of the body length, which fits within the length-range of those reported for C. rudolphii, but is a smaller percentage of total body length. The spicule tips are similar to those of C. rudolphii, and apparently, the postanal papillae are similar in the two species.

We have seen a third species represented by a few specimens. Contracaecum micropapillatum (Stossich 1890) infected one migrating White Pelican. Oglesby (1960, Auk 77: 354 ) reported more than 1,100 specimens identified as "probably C. micropapillatus" from a dead White Pelican in Apalachee Bay, Florida.

We wish to thank W. Guthrie Perry of the Louisiana Fish and Wildlife Commission for providing space and assistance at Rockefeller Refuge; Richard Heard, at that time with the Southeastern Cooperative Wildlife Disease Study, and Charles Courtney for supplying some material from the Brown Pelican; and Donald Norris of the University of Southern Mississippi for examining the gavaged rats. This study was conducted in cooperation with the U.S. Department of Commerce, NOAA, National Marine Fisheries Service, under PL 88-309 Project No. 2-325-R and HEW-Public Health Service, Food and Drug Administration Contract No. 223-76-2141. 